\title{
In Vitro Anti-Helicobacter pylori and Antimycobacterial Activity Evaluation of Selected Plants From Turkey
}

\author{
Ayșe Esra KARADAĞ* Ayșegül ÇAŞKURLU Fatma TOSUN \\ Istanbul Medipol University, School of Pharmacy, Department of Pharmacognosy, Istanbul, Turkey
}

How to cite: Karadağ, A.E., Çașkurlu, A. \& Tosun, F. (2020). In Vitro Anti-Helicobacter pylori and Antimycobacterial Activity Evaluation of Selected Plants From Turkey. J. Anatolian Env. and Anim. Sciences, 5(2), 231-235.

Atıf yapmak için: Karadağ, A.E., Çaşkurlu, A. \& Tosun, F. (2020). Türkiye'de Yetiştirilen Bazı Bitkilerin İn Vitro Anti-Helikobakter pilori ve Antimikobakteriyel Aktivitesi. Anadolu Çev. ve Hay. Dergisi, 5(2), 231-235.

*Corresponding author's: Ayșe Esra KARADAĞ

Istanbul Medipol University, School of Pharmacy, Department of Pharmacognosy, Istanbul, Turkey

$\triangle:$ ayseesraguler@gmail.com

Telephone $\quad:+90(216) 6815100$

Fax $\quad:+90(212) 5212377$
Abstract: In this study, the extracts of Ulmus minor Mill. subsp. minor (Ulmaceae), Lathyrus pratensis L. (Leguminosae), Glaucium leiocarpum Bois. (Papaveraceae), and Echium vulgare L. (Boraginacea) were investigated for their in vitro anti-Helicobacter pylori and antimycobacterial activity.

The air-dried plant material was powdered and extracted with $70 \%$ ethanol by maceration. The extract was filtered and evaporated to dryness under the vacuum and then dissolved in a waterethanol (90:10) mixture and extracted with dichloromethane and ethyl acetate, respectively. Antibacterial activity was investigated by microdilution method against Helicobacter pylori ATCC 43504, Mycolicibacterium smegmatis ATCC 14468 and Mycobacterium avium ATCC 25291.

The ethyl acetate extract of $U$. minor showed activity with MIC of $250 \mu \mathrm{g} / \mathrm{mL}$ against $H$. pylori. The other extracts showed no or weak inhibitory activity at $>2000 \mu \mathrm{g} / \mathrm{mL}$ concentrations against the tested microorganisms. In conclusion, ethyl acetate extract of $U$. minor may be used for the treatment of $H$. pylori infections.

Keywords: Echium, Glaucium, Helicobacter pylori, Lathyrus, Mycobacterium, Ulmus.

\section{Türkiye'de Yetiştirilen Bazı Bitkilerin İn Vitro Anti-Helikobakter pilori ve Antimikobakteriyel Aktivitesi}

*Sorumlu yazar:

Ayșe Esra KARADAĞ

İstanbul Medipol Üniversitesi, Eczacıllk

Fakültesi, Farmakognozi Anabilim Dalı, İstanbul, Türkiye.

\: ayseesraguler@gmail.com

Telefon $\quad:+90(216) 4607777$

Fax $\quad:+90(212) 5212377$
Öz: Bu çalışmada, Ulmus minor Mill. subsp. minor (Ulmaceae), Lathyrus pratensis L. (Leguminosae), Glaucium leiocarpum Bois. (Papaveraceae) ve Echium vulgare L. (Boraginacea) ekstrelerinin antihelikobakter pilori ve antimikobakter aktiviteleri in vitro olarak incelenmiştir. Kurutulmuş bitki materyalleri toz edildikten sonra \%70'lik etanolle masere edilmiştir. Ekstreler süzülerek vakum altında yoğunlaştırıldıktan sonra su-etanol (90:10) karışımında çözülerek sırasıyla diklorometan ve etilasetat ile alt ekstreleri hazırlanmıştır. Antibakteriyel aktivitesi in vitro broth mikrodilüsyon yöntemi ile Helicobacter pylori ATCC 43504, Mycolicibacterium smegmatis ATCC 14468 ve Mycobacterium avium ATCC 25291'a karşı araştırılmıştır. U. minor'un etilasetat ekstresinin MIKK değeri $H$. pilori' ye karş $1250 \mu \mathrm{g} / \mathrm{mL}$ olarak kaydedilmiştir. Test edilen konsantrasyonlarda $(2000 \mu \mathrm{g} / \mathrm{mL})$ diğer ekstreler belirgin bir MIK değeri göstermemiştir. Sonuç olarak $U$. minor yapraklarının etilasetat ekstresinin $H$. pilori enfeksiyonlarında tedavi edici olarak kullanılabileceği düşünülmektedir.

Anahtar kelimeler: Echium, Glaucium, Helikobakter pilori, Lathyrus, Mikobakter, Ulmus. 


\section{INTRODUCTION}

Mycobacterium species can be found in soil, water, dust particles, domestic or wild animals, milk and other nutrients and can be transmitted to humans from the environment. They can be colonized on body surface and secretions. Mycobacterium avium complex causes various ailments in humans and animals (Thorel et al., 2001). Mycobacterium avium complex contains the factors of $M$. avium subsp. paratuberculosis. The agent of $M$. paratuberculosis causes ruminant and other mammal species called Johne disease or paratuberculosis (Biet et al., 2005; Hoop, 2002; Tell et al., 2001). Mycolicibacterium smegmatis is a rapid-growing bacterium and it is used instead of M. tuberculosis and M. leprae in studies (Bashiri \&Baker, 2005).

Ulmus minor Mill. subsp. minor belongs to the Ulmaceae family and this family represented by three species in Turkey (Davis, 1982). Also, there are different Ulmus species around the world such as, Britain, Japan, Korea, China (Armstrong et al., 1996; Choi et al., 2010). There are no medicinal uses of $U$. minor subsp. minor in Turkey. However, the bark of the root and stem of $U$. davidiana var. japonica has been used as a traditional Korean medicine. It is used to treat inflammatory disorders and exhibits antioxidant, anticancer, and anti-inflammatory effects (Choi et al., 2010). To treat alopecia; some galls which are found on the branch and stem of the tree are cut and the juice and worms inside the galls are applied to the affected area of the head. The treatment should be repeated for several consecutive day. For scabies; the thin layer under the bark of branches (called 'sirri') is peeled, boiled with water until thick, then applied to the affected part (Yeşilada et al., 1999). Moreover, leaves of $U$. minor are used in veterinary treatment to cure digestion problems of rabbits and ovines in traditional usage in Tuscany (Italy) (Manganelli et al., 2001) Ulmus species contain biologically active compounds, such as sesqui-terpenoids, triterpenes and flavonoids (Lee et al., 2008; Zheng et al., 2010).

Lathyrus L. (Fabaceae) genus has more than 160 species and Lathyrus species used different uses, such as alimentary, agricultural, industrial, ornamental, and in traditional medicine worldwide (Lee et al., 2008; Zheng et al., 2010). For instance, L. odoratus and L. sativus are used for agricultural processes in Turkey and L. paratensis showed moderate to strong antifungal bioactivity (Arabi \& Sardari, 2010). Moreover, in traditional medicine, it is used for different purposes such as analgesic (seed of L. sativus), anti-inflammatory (aerial parts of L. cicera), and antirheumatism (leaf of $L$. rotundifolius Willd. subsp. miniatus (Bieb. ex Stev.) Davis) in Turkey (Llorent-Martínez et al., 2017). Additionally, Holbrook et al. stated that many species contain novel amino acids and nitriles that are toxic. Though the toxicants are present in vegetative parts of the plant, they are more concentrated in the seeds. Lathyrism can be seen in humans and various animals such as horses, cattle, sheepdogs, rabbits, rats and mice (Holbrook et al., 2015).

Glaucium genus represented by 7 species in Turkey (Cullen, 1965). These species are rich in alkaloid content. Glaucium leiocarpum Boiss. (Papaveraceae) is widely distributed in Greece, Crete, Iran, Syria, Caucasia and Turkey, mostly on roadsides, stony fields and slopes. Glaucium genus' have antimicrobial, antiinflammatory, antitumoral and analgesic activity and potency to cure agerelated brain disorders and it is also shown that Glaucium species have been used in Iranian and Turkish herbal medicine as laxative, antidiabetic, hypnotic, antifungal and for treatment of dermatitis (Baytop, 1984; Bournine et al., 2013; Hakemi et al., 2017; Morteza-Semnani et al., 2003; Orhan et al., 2004; Soureshjan \& Heidari, 2014). G. leiocarpum named 'Kuş ekmeği', in Aydınlar Village (Erdemli/Mersin) and it has been used in traditional medicine as soothing, cough suppressant, intestinal softener and for culinary purposes (Eşen, 2008).

Echium vulgare L. (Boraginaceae) is originated in the Mediterranean and naturalized in Africa, South and North America, Canada, Asia (Japan), Europe (United Kingdom, Turkey), New Zeland and Australia (Klemow et al., 2002). Echium species contain pyrrolizidine alkaloids, naphthoquinones (such as shikonins). Shikonins exhibit potent antimicrobial, antifungal, anticonvulsive effect and phytotoxic properties and are frequently used as biomedicinals in Eastern medicine (Kelmow et al., 2002; Papageogiou et al., 1999; Parsons et al., 2001; Zhu et al., 2016). Moreover, E. vulgare leaves are used against dermatosis to traditionally cure animals in Tuscany (Italy) (Manganelli et al., 2001). Multiple sources recommend that the plant be taken internally as a tea, powder, tincture, or medicinal wine. Moreover, it is known that E. vulgare used for treating urinary tract disorders and as an aid in childbirth in North America. Although prolonged internal use of E. vulgare may be cause to hepatotoxicity (Klemow et al., 2002).

In this study, antimicrobial activity of the selected four plants against Helicobacter pylori and Mycobacter strains was investigated to find an alternative and natural solution to the microbial disease such as stomach disorders or Mycobacterial infections which caused by these microorganisms.

\section{MATERIAL AND METHOD}

Collection of plant material: The plant materials of Lathyrus pratensis L, Ulmus minor Miller ssp. Minor 
and Echium vulgare L. were collected in their flowering periods from Giresun-Şebinkarahisar. Glaucium leiocarpum Boiss. were collected from Ankara- Çankaya. Voucher specimens were deposited in the Herbarium of Istanbul Medipol University, School of Pharmacy, Department of Pharmacognosy.

Solvent extraction: The air-dried plant material was powdered and extracted with $70 \%$ ethanol by maceration. The extract was filtered and evaporated to dryness under reduced pressure in a rotary evaporator. The concentrated residue dissolved in a water-ethanol (90:10) mixture and then extracted with liquid-liquid extraction by dichloromethane (DCM) and ethyl acetate (EtOAc), respectively (Karadağ \& Tosun, 2019; Acet, 2019).

Antimicrobial Activity: The antimicrobial activity was studied using the broth microdilution assay by a modified Clinical and Laboratory Standards Institute protocol (CLSI) (Whitmire \& Merrell, 2012). All microorganisms were standardized versus McFarland No: 0.5 in sterile saline $(\% 0.85)$ turbidimetrically. The stock solutions of the extracts were dissolved in dimethylsulfoxide (DMSO), and serial dilutions were prepared. Diluted bacterial suspensions were added to each well and then incubated at $37{ }^{\circ} \mathrm{C}$ for twenty-four hours.

Helicobacter pylori ATCC 43504 were grown for 24 hours in Brucella broth containing 5\% (v/v) horse blood Colombia agar and containing $10 \%(\mathrm{~h} / \mathrm{h})$ fetal bovine serum (FBS) at $37{ }^{\circ} \mathrm{C}$ in an anaerobic incubator $\left(5 \% \mathrm{CO}_{2}\right)$. $100 \mu \mathrm{L}$ of $1: 10$ diluted and density modulated H. pylori's strain was added to each microplate. The MICs were calculated as the mean of three repetitions, which are reported in Table 1.

Mycobacterium strains were inoculated in Middlebrook 7H11 agar (Sigma Aldrich), and incubated in aerobic conditions at $37{ }^{\circ} \mathrm{C}$ for $4-5$ days. The microorganism was transferred to the cation doped MHB and incubated for a further five days. Growing cultures were vortexed and allowed to collapse for $30 \mathrm{~min}$. Diluted bacterial suspensions $\left(10^{6} \mathrm{CFU} / \mathrm{mL}\right)$ were added to each well and then allowed to incubate at $37{ }^{\circ} \mathrm{C}$ for 5 days. Amoxicillin, clarithromycin and tetracycline were used as positive control and DMSO used as negative control (Karadağ \& Tosun, 2019).

\section{RESULTS AND DISCUSSION}

Eight extracts were tested against the pathogenic bacteria listed in Table 1. Using a modified micro-broth dilution assay, MIC values of extracts were compared with those of amoxicillin, clarithromycin, and tetracycline. DMSO was used as negative control. 2000-62.5 $\mu \mathrm{g} / \mathrm{mL}$ concentration range was studied for determine the MIC value. Among the tested bacteria in this present study, $H$. pylori was the more sensitive to the $U$. minor EtOAc extract $(250 \mu \mathrm{g} / \mathrm{mL})$, while Mycobacteria appeared to be the most resistant $(>2000 \mu \mathrm{g} / \mathrm{mL})$. While a moderate antimicrobial activity was observed in $U$. minor extracts against $H$. pylori strain none of the other extracts showed activity against Mycobacterium species in the tested concentrations (i.e., $2 \mu \mathrm{g} / \mathrm{mL}$ ).

Table 1. Results of antimicrobial activity determined by microdilution method of samples $(\mu \mathrm{g} / \mathrm{mL})$ and antimicrobials $(\mu \mathrm{g} / \mathrm{mL})$.

\begin{tabular}{|l|c|c|c|}
\hline \multicolumn{1}{|l|}{ Samples } & H. pylori & M. smegmatis & M. avium \\
\hline G. leiocarpum DCM extract & 1000 & $>2000$ & $>2000$ \\
\hline G. leiocarpum EtOAC & $>2000$ & $>2000$ & $>2000$ \\
extract & & & \\
\hline E. vulgare DCM extract & $>2000$ & $>2000$ & $>2000$ \\
\hline E. vulgare EtOAc extract & $>2000$ & $>2000$ & $>2000$ \\
\hline U. minor DCM extract & $>2000$ & $>2000$ & $>2000$ \\
\hline U. minor EtOAc extract & 250 & $>2000$ & $>2000$ \\
\hline L. pratensis DCM extract & $>2000$ & $>2000$ & $>2000$ \\
\hline L. pratensis EtOAc extract & 1000 & $>2000$ & $>2000$ \\
\hline Amoxicillin & $\leq 0.125$ & NE & NE \\
\hline Clarithromycin & 25 & 64 & 8 \\
\hline Tetracycline & 25 & NE & NE \\
\hline *NE: No effect & & & \\
\hline
\end{tabular}

Although here are not many antimicrobial activity studies on the plants used in the study, there is a study showing that $G$. leiocarpum has an ethnobotanical use against wound healing (Bulut et al., 2017). However, antimicrobial activity of some secondary metabolites of $E$. vulgare was investigated, but efficacy was not observed at the tested concentrations (solutions of the pure compounds, solved in $\mathrm{MeOH}$, c $1 / 41 \mathrm{mg}=\mathrm{ml}$ ) against the tested microorganisms (Escherichia coli, Bacillus subtilis, Staphylococcus aureus and Candida albicans) (Kuruüzüm-Uz et al., 2004). In an antimicrobial activity screening study on Lathyrus species, the MIC value of ethyl acetate extract obtained from L. pratensis against the Staphylococcus aureus, Bacillus subtilis, Escherichia coli, and Pseudomonas aeruginosa and antifungal activity against Candida albicans were calculated as $0.5 \mathrm{mg} / \mathrm{mL}$ (Heydari et al., 2019). However, MIC values could not be calculated at the concentrations against the microorganisms used in this study.

\section{CONCLUSION}

In previous studies, antimicrobial activity of different extracts of $U$. minor stems and leaves were studied and various MIC values are obtained against Enterecoccus faecalis and Salmonella typhii (Tag et al., 2011) Leaves of $U$. minor is use in veterinary treatment to cure digestion problems of rabbits and ovines in traditional usage in Tuscany (Italy) (Manganelli et al., 2001). 
As a result, it can be thought that $U$. minor leaf extracts which are prepared by polar solvent such as methanol, ethanol, water etc. can be used as a supplementary to prevent stomach ulcer caused by $H$. pylori. In addition, this study can be evaluated in future studies to determine active compounds from EtOAc extract of $U$. minor leaves.

\section{REFERENCES}

Acet, T. (2019. A study on antioxidant properties and antimicrobial activity of various extracts of Carduus adpressus. Anatolian Env. and Anim. Sciences, 4(2), 409-413.

Arabi, Z. \& Sardari, S. (2010). An investigation into the antifungal property of Fabaceae using bioinformatics tools. Avicenna Journal of Medical Biotechnology, 2(2), 93.

Armstrong, J.V. \& Sell, P.D. (1996). A revision of the British elms (Ulmus L., Ulmaceae): the historical background. Botanical Journal of the Linnean Society, 120(1), 39-50.

Bashiri, G. \& Baker, E.N. (2015). Production of recombinant proteins in Mycobacterium smegmatis for structural and functional studies. Protein Science, 24(1), 1-10.

Baytop, T. (1984). Therapy with medicinal plants in Turkey (past and present), Publication no 325, Istanbul University, Istanbul, 189p.

Biet, F., Boschiroli, M.L., Thorel, M.F. \& Guilloteau, L.A. (2005). Zoonotic aspects of Mycobacterium bovis and Mycobacterium avium-intracellulare complex (MAC). Veterinary Research, 36(3), 411-436.

Bournine, L., Bensalem, S., Wauters, J.N., IguerOuada, M., Maiza-Benabdesselam, F., Bedjou, F., Castronovo, V., Bellahcene, A., Tits, M. \& Frédérich, M. (2013). Identification and quantification of the main active anticancer alkaloids from the root of Glaucium flavum. International Journal of Molecular Sciences, 14(12), 23533-23544.

Bulut, G., Haznedaroğlu, M.Z., Doğan, A., Koyu, H. \& Tuzlaci, E. (2017). An ethnobotanical study of medicinal plants in Acipayam (Denizli-Turkey). Journal of Herbal Medicine, 10, 64-81.

Choi, S.Y., Lee, S., Choi, W.H., Lee, Y., Jo, Y.O. \& Ha, T.Y. (2010). Isolation and anti-inflammatory activity of Bakuchiol from Ulmus davidiana var. japonica. Journal of Medicinal Food, 13(4), 1019-1023.

Cullen, J. (1965). Glaucium Mill. in: Davis P.H. (Ed.) Flora of Turkey and the East Aegean islands, Vol 1., pp. 214-217, Edinburgh University Press, Edinburgh.

Davis, P.H. (1982). Flora of Turkey and East Aegean Islands, University Press, Edinburgh.

Eşen, B. (2008). Aydınlar köyü ve çevresinin (Erdemli/Mersin) etnobotanik özellikleri, Doktora
Tezi, Selçuk Üniversitesi Fen Bilimleri Enstitüsü 110 s.

Hakemi-Vala, M., Mehrara, M., Pourramezan, M., Rahimifard, J.A.N., Khoshnood, S. \& Heidary, M. (2017). Comparison the antimicrobial effects of the flowering aerial parts of Glaucium vitellinum Boiss. and Buhse and Gaillonia aucheri Jaub. and Spach. Novelty in Biomedicine, 5, 24-29.

Heydari, H., Saltan İşcan, G., Eryılmaz, M., Bahadır Acıkara, Ö., Yılmaz Sarıaltın, S., Tekin, M. \& Çoban, T. (2019). Antimicrobial and antiinflammatory activity of some Lathyrus L. (Fabaceae) species growing in Turkey. Turkish Journal of Pharmaceutical Sciences, 16(2), 240245.

Holbrook, T.C., Gilliam, L.L., Stein, F.P., Morgan, S.E., Avery, A.L., Confer, A.W. \& Panciera, R.J. (2015). Lathyrus hirsutus (Caley Pea) intoxication in a herd of horses. Journal of Veterinary Internal Medicine, 29(1), 294-298.

Hoop, R.K. (2002). Mycobacterium tuberculosis infection in a canary (Serinus canaria L.) and a bluefronted Amazon parrot (Amazona amazona aestiva). Avian Diseases, 46(2), 502-504.

Karadağ, A.E. \& Tosun, F. (2019). In vitro antimicrobial and antioxidant activity evaluation of melampyrum arvense L. var. elatius boiss. and sedum spurium m. bieb. extracts. ACTA Pharmaceutica Sciencia, 57(2), 193-201.

Klemow, K.M., Clements, D.R., Threadgill, P.F. \& Cavers, P.B. (2002). The biology of Canadian weeds. 116. Echium vulgare L. Canadian Journal of Plant Science, 82(1), 235-248.

Kuruüzüm-Uz, A., Güvenalp, Z., Ströch, K., Demirezer, L.Ö. \& Zeeck, A. (2004). Phytochemical and antimicrobial investigation of Echium vulgare growing in Turkey. Biochemical Systematics and Ecology, 32(9), 833-836.

Lee, G.Y., Jang, D.S., Kim, J., Kim, C.S., Kim, Y.S., Kim, J.H. \& Kim, J.S. (2008). Flavan-3-ols from Ulmus davidiana var. japonica with inhibitory activity on protein glycation. Planta Medica, 74(15), 1800-1802.

Llorent-Martínez, E.J., Zengin, G., Fernández-de Córdova, M.L., Bender, O., Atalay, A., Ceylan, R., ... \& Aktumsek, A. (2017). Traditionally used Lathyrus species: phytochemical composition, antioxidant activity, enzyme inhibitory properties, cytotoxic effects, and in silico studies of L. czeczottianus and L. nissolia. Frontiers in Pharmacology, 8, 83.

Manganelli, R.U., Camangi, F. \& Tomei, P.E. (2001). Curing animals with plants: traditional usage in Tuscany (Italy). Journal of Ethnopharmacology, 78(2-3), 171-191.

Morteza-Semnani, K., Amin, G., Shidfar, M.R., Hadizadeh, H. \& Shafiee, A. (2003). Antifungal activity of the methanolic extract and alkaloids of Glaucium oxylobum. Fitoterapia, 74(5), 493-496. 
Orhan, I., Şener, B., Choudhary, M.I. \& Khalid, A. (2004). Acetylcholinesterase and butyrylcholinesterase inhibitory activity of some Turkish medicinal plants. Journal of Ethnopharmacology, 91(1), 57-60.

Papageorgiou, V.P., Assimopoulou, A.N., Couladouros, E.A., Hepworth, D. \& Nicolaou, K.C. (1999). The chemistry and biology of alkannin, shikonin, and related naphthazarin natural products. Angewandte Chemie International Edition, 38(3), 270-301.

Parsons, W.T., Parsons, W.T. \& Cuthbertson, E.G. (2001). Noxious weeds of Australia. CSIRO publishing.

Soureshjan, E. H., \& Heidari, M. (2014). In vitro Variation in antibacterial activity plant extracts on Glaucium elegans and Saffron (Crocus sativus L.) Onios. Electronic Journal of Biology, 10, 64-67.

Tağ, Ö., Yaşa, I., Polat, E., Özgökçe, F. \& Karayıldırım, T. (2011). Anti-microbial activities of leaves and stems of Ulmus minor Miller subsp. minor. Planta Medica, 77(12), PM151.

Tell, L.A., Woods, L. \& Cromie, R.L. (2001). Mycobacteriosis in birds. Revue Scientifique et Technique-Office International des Epizooties, 20(1), 180-203.

Thorel, M.F., Huchzermeyer, H.F. \& Michel, A.L. (2001). Mycobacterium avium and Mycobacterium intracellulare infection in mammals. Rev. Sci. Tech., 20, 204-18.

Whitmire, J.M. \& Merrell, D.S. (2012). Successful culture techniques for Helicobacter species: general culture techniques for Helicobacter pylori. In Helicobacter Species (pp. 17-27). Humana Press, Totowa, NJ.

Yeşilada, E., Sezik, E., Honda, G., Takaishi, Y., Takeda, Y. \& Tanaka, T. (1999). Traditional medicine in Turkey IX: Folk medicine in north-west Anatolia. Journal of Ethnopharmacology, 64(3), 195-210.

Zheng, M.S., Yang, J.H., Li, Y., Li, X., Chang, H.W. \& Son, J.K. (2010). Anti-inflammatory activity of constituents isolated from Ulmus davidiana var. japonica. Biomolecules \& Therapeutics, 18(3), 321-328.

Zhu, X., Skoneczny, D., Weidenhamer, J.D., Mwendwa, J.M., Weston, P.A., Gurr, G. M., Callaway, R.M. \& Weston, L.A. (2016). Identification and localization of bioactive naphthoquinones in the roots and rhizosphere of Paterson's curse (Echium plantagineum), a noxious invader. Journal of Experimental Botany, 67(12), 3777-3788. 